\title{
HUBUNGAN HARGA DIRI DAN PENGETAHUAN TENTANG BULLYING DENGAN PERILAKU BULLYING PADA REMAJA
}

\author{
Anissa Duwi Nur A'ini ${ }^{1}$, Andriati Reny $\mathrm{H}^{2}$ \\ ${ }^{1,2}$ STIKes Jayakarta program studi Sarjana Keparawatan \\ E-mail: anissaduwinuraini@gmail.com
}

\begin{abstract}
Abstrak
Perilaku bullying adalah sebuah hasrat untuk meyakiti baik secara fisik, psikis atau verbal, yang menyebabkan seseorang menderita. Salah satu faktor penyebab seorang remaja melakukan bullying adalah harga diri dan pengetahuan. Penelitian ini bertujuan untuk mengetahui hubungan harga diri dan pengetahuan tentang bullying dengan perilaku bullying pada remaja. Populasi penelitian adalah kelas X dan XI sebanyak 1093 responden, dengan jumlah sampel sebanyak 190 responden di SMK Insan Kreatif Cibinong-Bogor dengan teknik pengambilan sampel yang digunakan adalah stratified random sampling. Hasil analisis data menggunakan uji chi-square dengan tingkat kepercayaan 95\% ( $p$-value $=0,05)$. Hasil dari penelitian ini menunjukkan bahwa terdapat hubungan yang signifikan antara harga diri dengan perilaku bullying pada remaja dengan $p$-value $=0,000$ dan terdapat hubungan antara pengetahuan tentang bullying dengan perilaku bullying pada remaja dengan $p$-value $=0,002$.
\end{abstract}

Kata Kunci : Bullying, Harga Diri, Pengetahuan.

\begin{abstract}
Bullying behavior is a desire to hurt both physically, psychologically or verbally, which causes a person to suffer. One of the factors that causes a teen to do bullying is self-esteem and knowledge. The purpose of this research is to determine the relationship between self-esteem and knowledge about bullying with bullying behavior on adolescents. The population of the research is was the class X and XI as many as 1093 respondents, with a total sample of 190 respondents in the SMK Insan Kreatif Cibinong-Bogor with the sampling technique used was stratified random sampling. The results of the research using the chi-square test with a confidence level of 95\% ( $p$-value =0.05). The results of this study indicate that there is a significant relationship between self-esteem and bullying behavior in adolescents with $p$-value $=0,000$ and there is a relationship between knowledge about bullying and bullying behavior in adolescents with $p$-value $=0.002$.
\end{abstract}

Keyword $\quad$ : Bullying, Self-Esteem, Knowledge.

\section{Pendahuluan}

Bullying adalah sebuah hasrat untuk meyakiti. Hasrat ini diperhatikan ke dalam aksi secara fisik, psikis atau verbal, yang menyebabkan seseorang menderita (Astuti,2008). Masalah kesehatan psikologis remaja ini dapat terjadi dimanapun dan kapanpun. Fenomena bullying pada remaja bukanlah hal baru. Hingga kini masih mendapat perhatian khusus dan ditangani secara serius.
Berdasarkan data dari United Nations Children's Fund (UNICEF) pada tahun 2014 didapatkan data sebanyak $40 \%$ anak mengalami bully di sekolah, 32\% melaporkan mendapat kekerasan fisik, $72 \%$ anak dan remaja menjadi saksi kekerasan terhadap anak. Pemerintah setuju untuk mengurangi semua bentuk kekerasan terhadap anak-anak (UNICEF,2017). 
Menurut Komisi Perlindungan Anak Indonesia (KPAI) pada tahun 2016 kasus kekerasan pada anak terutama perilaku bullying sebanyak 5.066 kasus. Sulit untuk memutus mata rantai kasus bully pada anak yang menjadi permasalahan sampai saat ini. Sebab, korban bisa menjadi pelaku dan pelaku dapat pula menjadi korban (KPAI, 2017). Menurut Pemerintahan Kota Bogor, perilaku bullying yang terjadi di kota Bogor berdasarkan Junior Chamber Internasional (JCI) pada tahun 2016 sebanyak 30 sampai 40 persen dari korban bullying masih berusia sekolah (SD, SMP, SMA), dan 60 sampai 70 persen pada perguruan tinggi.

Salah satu faktor yang menyebabkan perilaku bullying, yaitu harga diri. Seseorang yang memiliki harga diri yang kuat akan mampu membina relasi yang lebih baik dan sehat dengan orang lain, bersikap sopan dan menjadikan dirinya menjadi orang yang berhasil. Sebaliknya jika seseorang yang memiliki harga diri yang lemah citra diri yang negatif dan kosep diri yang buruk, akan menjadi penghalang kemampuannya sendiri dalam membentuk satu hubungan. Penghargaan diri yang rendah akan memicu seseorang untuk melakukan dua sikap ekstrim yang merugikan yaitu sikap pasif dan sikap agresif. Sikap pasif yaitu sikap yang tidak tegas dan tersinggung, merasa diperintah atau digurui yang membuat diri menjadi benci dan merasa dikucilkan. Sikap agresif yaitu memaksakan gagasan, tidak mau menerima masukan dari orang lain, dan cenderung tertutup dalam menyelesaikan masalah (Suhron, 2017). Berdasarkan hasil penelitian Fithria dan Rahmi (2016) yang dilakukan di SMPN 3 Meureudu Kabupaten Pidie Jaya, terdapat beberapa faktor yang menyebabkan anak melakukan tindakan bullying, salah satunya yaitu faktor harga diri dengan perilaku bullying.

Faktor lain yang dapat mempengaruhi perilaku bullying adalah faktor pengetahuan. Menurut teori Green (1980) dalam Notoatmodjo (2010) menyatakan bahwa salah satu faktor yang menentukan perilaku seseorang yaitu pengetahuan. Tingkat pengetahuan yang baik diharapkan dapat membentuk perilaku positif seseorang untuk tidak melakukan perilaku bullying. Berdasarkan hasil penelitian Fajrin, (2013) yang dilakukan di SMK PGRI Semarang menunjukkan bahwa ada hubungan tingkat pengetahuan dengan perilaku bullying di dapatkan nilai p-value sebesar 0.001. Semakin tinggi tingkat pengetahuan remaja tentang bullying, maka semakin rendah tingkat kejadian bullying, sebaliknya semakin rendah tingkat pengetahuan remaja tentang bullying, maka semakin tinggi tingkat kejadian bullying.

Berdasarkan hasil studi pendahuluan yang di lakukan di SMK Insan Kreatif, CibinongBogor pada 11 responden melalui 3 
pertanyaan diperoleh hasil sebanyak 5 orang $(50 \%)$ mengatakan tidak tahu tentang dampak perilaku bullying, dan sebanyak 6 orang (60\%) mengatakan bahwa pernah melakukan bullying secara verbal. Berdasarkan uraian tersebut, maka perlu dilakukan penelitian mengenai hubungan harga diri dan pengetahuan tentang bullying dengan perilaku bullying di SMK Insan Kreatif CibinongBogor.

\section{Tinjauan Teori}

Bullying berasal dari bahasa inggris yaitu dari kata bull yang artinya banteng yang senang menyeruduk kesana kemari. Istilah ini pun kemudian di ambil untuk menguraikan suatu tindakan destruktif. Dalam bahasa Indonesia secara etimologi kata bully yang berarti penggertak, orang yang mengganggu orang lemah (Wiyani, 2012). Sedangkan menurut Astuti (2008) Bullying adalah sebuah hasrat untuk meyakiti. Hasrat ini diperhatikan ke dalam aksi secara fisik, psikis atau verbal, yang menyebabkan seseorang mederita. Aksi tersebut dilakukan secara langsung oleh seseorang atau kelompok yang lebih kuat. tidak bertanggung jawab, berulang, dan dilakukan dengan perasaan senang.

Menurut Priyatna (2010) bullying memiliki macam-macam sesuai tindakan yang dilakukan antara lain fisikal, Verbal, social dan Cyber. Fisikal yaitu suatu tindakan dengan melakukan secara fisik seperti memukul, menendang, mendorong, merusak benda-benda milik korban termasuk tindakan pencurian.

Verbal yaitu suatu tindakan menggejek, mengolok-olok nama panggilan, melecehkan penampilan, mengancam, menakut-nakuti. Sosial yaitu tindakan yang dilakukan dengan cara menyebar gossip, rumor, mempermalukan di depan umum, dikucilkan dari pergaulan, menjebak seseorang sehingga seseorang tersebut yang dituduh melakukan tindakan tersebut. Cyber atau elektronik yaitu suatu tindakan membully melalui media sosial dengan cara mempermalukan orang dengan menyebar gossip dijejaring sosial internet seperti facebook atau friendster, menyebar foto pribadi tanpa izin pemiliknya di internet, atau membokar rahasia orang lain lewat internet atau SMS.

Tindakan bullying akan berakibat buruk bagi korbannya bahkan efek dari perilaku bullying tersebut akan membekas sampai si anak telah dewasa. Dampak buruk yang dapat terjadi pada anak yang menjadi korban tindakan bullying antara lain kecemasan, merasa kesepian, rendah diri, dan depresi, symptom psikosomatik, penarikan sosial, keluhan pada kesehatan fisik, pergi dari rumah, penggunaan alkohol dan obat-obatan, bunuh diri, dan penurunan peformasi akademik. Sedangkan dampak jangka panjang seseorang yang menjadi pelaku bullying antara lain menjadi 
orang dewasa yang agresif dan Sering terlibat dalam tidakan kekerasan (Priyatna, 2010).

Bullying memberikan efek negatif pada remaja yang dapat berlanjut pada masa dewasa. Bullying terjadi ketika seseorang secara berulang mencoba menyakiti orang yang lebih lemah dari dirinya atau rentan. Bully lebih sering dilakukan oleh remaja yang lebih muda dibandingkan yang tua. Seiring dengan bertambahnya usia remaja, mereka cenderung menjadi jarang melakukan bully atau menjadi korban bullying (Stuart,2016).

Menurut Fortinash, et all (1999) harga diri ialah perasaan tentang nilai, harga atau manfaat dari diri sendiri yang berasal dari kepercayaan positif maupun negatif dari seorang individu tentang kemampuan dirinya untuk menjadi berharga (Dermawan dan Rusdi, 2013). Terdapat berbagai macam pengukuran harga diri menurut yaitu The self-esteem scale oleh Rosenberg pada tahun 1965. Alat ukur ini mengukur keberhargaan diri dan penerimaan diri individu secara global. Instrumen pengukuran self-esteem ini memiliki nilai koefesien reliabilitas Alpha Cronbach sebesar 0,8054 (Suhron, 2017).

Pengetahuan merupakan hasil dari "tahu" dan terjadi setelah orang mengadakan penginderaan terhadap suatu objek tertentu. Menurut Agus dan Budiman (2014) pengetahuan ialah suatu pembentukan yang terus-menerus oleh seseorang yang setiap saat mengalami perkembangan dalam reorganisasi karena adanya pemahamanpemahaman. Menurut Wawan dan Dewi (2010), faktor yang mempengaruhi pengetahuan anatra lain faktor internal yaitu pendidkan, pekerjaan dan umur. Sedangkan faktor eksternal yaitu faktor lingkungan dan sosial budaya.

\section{Metodologi}

Penelitian ini merupakan penelitian kuantitatif analitik dengan desain penelitian yang digunakan yaitu cross sectional. Populasi pada penelitian ini yaitu siswa/siswi di SMK Insan Kreatif Cibinong-Bogor kelas X dan XI sebanyak 1093 responden. Jumlah sampel yang di gunakan pada penelitian ini sebanyak 190 responden yang terdiri dari jumlah kelas X sebanyak 92 responden dan kelas XI sebanyak 98 responden. Tehnik pengambilan sampel menggunakan tehnik Stratified Random Sampling yaitu pengelompokan suatu populasi yang terdiri dari unit yang mempunyai karakteristik yang berbeda-beda atau heterogen yang dilakukan di SMK Insan Kreatif.

Proses penelitian dilaksanakan selama bulan April-Mei 2019. Sumber data pada penelitian ini yaitu data primer. Instrumen yang digunakan pada penelitian ini menggunakan kuesioner yang dengan 49 item pernyataan yang terdiri dari 3 pernyataan yaitu harga diri 
(self esteem) dengan 10 item pernyataan, pengetahuan tentang bullying sebanyak 22 item pernyataan, dan perilaku bullying dengan 17 item penyataan.

Hasil pengujian validitas pada variabel pengetahuan tentang bullying dengan 30 responden menggunakan rumus Kuder Richardson didapatkan nilai $r$ hitung $(0,89)>$ $r$ tabel $(0,361)$ yang artinya valid. Hasil pengujian validitas pada variabel perilaku bullying menggunakan rumus kuder Richardson didapatkan nilai $\mathrm{r}$ hitung $(0,70)>$ $\mathrm{r}$ tabel $(0,361)$ yang artinya valid.

Pernyataan tentang harga diri tidak dilakukan uji validitas, dikarenakan kuesioner harga diri yang digunakan yaitu Rosenberg Self-Esteem Scale. Analisa data yang menggunakan uji Chi-Square untuk melihat hubungan antara variabel yang diteliti dengan tingkat kemaknaan sebesar $\alpha \leq 0,005$.

Berdasarkan tabel 1 menunjukkan bahwa sebagian besar responden berjenis kelamin laki-laki sebanyak 142 orang $(74,7 \%)$.

Berdasarkan tabel 2 menunjukkan bahwa sebagian besar responden berada pada tahapan remaja akhir (17-20 tahun) sebanyak 98 orang $(51,6 \%)$.

\section{Hasil}

\section{Karakteristik Responden}

Tabel 1. Distribusi Frekuensi Responden Berdasarakan Jenis Kelamin $(n=190)$

\begin{tabular}{lcc}
\hline Jenis kelamin & Frekuensi & Presentase \\
\hline Laki-laki & 142 & 74,7 \\
\hline Perempuan & 48 & 25,3 \\
\hline \multicolumn{1}{c}{ Jumlah } & $\mathbf{1 9 0}$ & $\mathbf{1 0 0}$ \\
\hline
\end{tabular}

Tabel 2. Distribusi Frekuensi Responden Berdasarkan Usia $(n=190)$

\begin{tabular}{lcc}
\hline \multicolumn{1}{c}{ Usia } & Frekuensi & Persentase \\
\hline $\begin{array}{l}\text { Remaja } \\
\text { Pertengahan } \\
(13-16 \text { Tahun) }\end{array}$ & 92 & 48,4 \\
\hline $\begin{array}{l}\text { Remaja Akhir } \\
(17-20 \text { Tahun })\end{array}$ & 98 & 51,6 \\
\hline Jumlah & $\mathbf{1 9 0}$ & $\mathbf{1 0 0}$ \\
\hline
\end{tabular}

\section{Gambaran Harga Diri}

Tabel 3. Distribusi Frekuensi Responden Berdasarkan Harga Diri $(n=190)$

\begin{tabular}{lcc}
\hline Harga Diri & Frekuensi & Persentase \\
\hline $\begin{array}{l}\text { Harga Diri } \\
\text { Rendah }\end{array}$ & 93 & 48,9 \\
\hline $\begin{array}{l}\text { Harga Diri } \\
\text { Tinggi }\end{array}$ & 97 & 51,1 \\
\hline Jumlah & $\mathbf{1 9 0}$ & $\mathbf{1 0 0}$ \\
\hline
\end{tabular}

Hasil penelitian pada tabel 3 menunjukkan bahwa sebagian besar remaja memiliki harga diri yang tinggi sebesar 97 responden $(51,1 \%)$. 


\section{Gambaran Pengetahuan Tentang Bullying}

Tabel 4. Distribusi Frekuensi Responden Berdasarkan Pengetahuan Tentang Bullying $(\mathrm{n}=190)$

\begin{tabular}{lcc}
\hline \multicolumn{1}{c}{ Pengetahuan } & Frekuensi & Persentase \\
\hline $\begin{array}{l}\text { Pengetahuan } \\
\text { Kurang }\end{array}$ & 86 & 45,3 \\
\hline Pengetahuan Baik & 104 & 54,7 \\
\hline Jumlah & $\mathbf{1 9 0}$ & $\mathbf{1 0 0}$ \\
\hline
\end{tabular}

Berdasarkan tabel 4 menunjukkan bahwa sebagian besar memiliki pengetahuan baik tentang bullying sebanyak 104 responden $(54,7 \%)$.

\section{Gambaran Kejadian Perilaku Bullying}

Tabel 5. Distribusi Frekuensi Responden Berdasarkan Perilaku Bullying $(\mathrm{n}=190)$

\begin{tabular}{lcc}
\hline Perilaku Bullying & Frekuensi & Persentase \\
\hline Bullying Rendah & 80 & 42,1 \\
\hline Bullying Tinggi & 110 & 57,9 \\
\hline Jumlah & $\mathbf{1 9 0}$ & $\mathbf{1 0 0}$ \\
\hline
\end{tabular}

Berdasarkan tabel 5 menunjukkan bahwa sebagian besar remaja melakukan perilaku bullying tinggi sebanyak 110 responden $(57,9 \%)$.

Berdasarkan tabel 6 menunjukkan bahwa ada hubungan ada hubungan bermakna antara harga diri dengan perilaku bullying pada remaja dengan nilai p-Value sebesar 0,000. Remaja yang memiliki harga diri rendah sebanyak 0,188 kali berpeluang lebih besar melakukan perilaku bullying dibandingkan dengan remaja yang memiliki harga diri tinggi.

\section{Hubungan Harga Diri dengan Perilaku Bullying}

Tabel 6. Hubungan Harga Diri Dengan

Perilaku Bullying Pada Remaja $(n=190)$

\begin{tabular}{|c|c|c|c|c|c|}
\hline \multirow{3}{*}{$\begin{array}{l}\text { Harga } \\
\text { Diri }\end{array}$} & \multicolumn{2}{|c|}{ Perilaku Bullying } & \multirow{3}{*}{$\begin{array}{l}\text { To- } \\
\text { tal }\end{array}$} & \multirow{3}{*}{$\begin{array}{c}\text { P- } \\
\text { Value }\end{array}$} & \multirow{3}{*}{ OR } \\
\hline & $\begin{array}{l}\text { Bullying } \\
\text { Rendah }\end{array}$ & $\begin{array}{c}\text { Bullying } \\
\text { Tinggi }\end{array}$ & & & \\
\hline & $\%$ & $\%$ & & & \\
\hline Rendah & 2122,6 & $\begin{array}{ll}72 & 77,4\end{array}$ & 93 & & \\
\hline Tinggi & 5960,8 & $38 \quad 39,2$ & 97 & & \\
\hline Jumlah & $\begin{array}{ll}80 & 42,1\end{array}$ & $\begin{array}{ll}110 & 57,9\end{array}$ & 190 & & \\
\hline
\end{tabular}

\section{Hubungan Pengetahuan Tentang Bully dengan Perilaku Bullying}

\section{Tabel 7. Hubungan Pengetahuan Tentang} Bullying Dengan Perilaku Bullying Pada $(\mathbf{n}=190)$

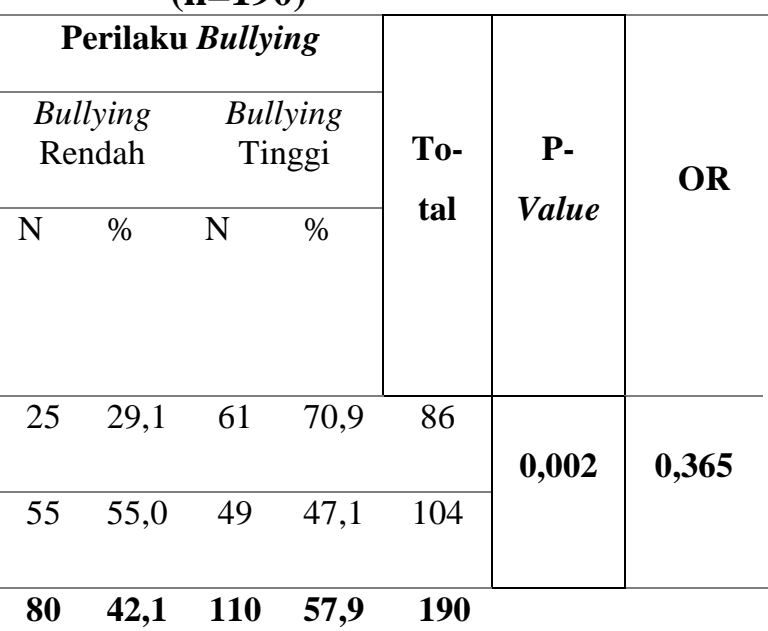

Berdasarkan tabel 7 menjelaskan bahwa ada hubungan antara pengetahuan tentang bullying dengan perilaku bullying pada remaja dengan nilai $p$-value 0,002. Remaja yang memiliki pengetahuan kurang sebanyak 0,365 
kali berpeluang lebih besar melakukan perilaku bullying dibandingkan dengan yang memiliki pengetahuan baik.

\section{Pembahasan}

\section{Hubungan Harga Diri dengan Perilaku}

\section{Bullying}

Berdasarkan hasil penelitian menjelaskan bahwa ada hubungan yang bermakna antara harga diri dengan perilaku bullying pada remaja dengan nilai p-Value sebesar 0,000. Selain itu, diperoleh data bahwa remaja dengan harga diri rendah sebanyak 0,188 kali berpeluang lebih besar melakukan perilaku bullying dibandingkan dengan remaja yang memiliki harga diri tinggi.

Hasil penelitian ini sejalan dengan penelitian yang dilakukan oleh Purnaningtyas dan Achmad (2015) menyatakan bahwa terdapat hubungan antara konsep diri dengan kecenderungan bullying siswa SMK Negri 10 Semarang. Hal tersebut dibuktikan dengan angka korelasi -0,450 dan tingkat signifikan $\mathrm{p}=0,000$. Selain itu, sejalan pula dengan hasil penelitian yang dilakukan oleh Ceilindri dan Meita (2016), menyatakan bahwa terdapat hubungan yang signifikan antara harga diri dan konformitas dengan perilaku bullying dengan p- value 0,000. Apabila harga diri rendah maka konformitas cenderung tinggi dan akan memunculkan perilaku bullying.
Menurut Fortinash, et all (1999) harga diri ialah perasaan tentang nilai, harga atau manfaat dari diri sendiri yang berasal dari kepercayaan positif maupun negatif dari seorang individu tentang kemampuan dirinya untuk menjadi berharga (Dermawan dan Rusdi, 2013).

Seseorang yang memiliki harga diri yang kuat akan mampu membina relasi yang lebih baik dan sehat dengan orang lain, bersikap sopan dan menjadikan dirinya menjadi orang yang berhasil. Sebaliknya jika seseorang yang memiliki harga diri yang lemah citra diri yang negatif dan kosep diri yang buruk, semua kan menjadi penghalang kemampuannya sendiri dalam membentuk satu hubungan antar individu agar nyaman dan baik untuk dirinya. Penghargaan diri yang rendah akan memicu seseorang untuk melakukan dua sikap ekstrem yang merugikan yaitu sikap pasif dan sikap agresif. Sikap pasif yaitu sikap yang tidak tegas dan tersinggung, merasa diperintah atau digurui yang membuat diri menjadi benci dan merasa dikucilkan. Sikap agresif yaitu memaksakan gagasan, tidak mau menerima masukan dari orang lain, dan cenderung tertutup dalam menyelesaikan masalah (Suhron,2017).

Menurut Coopersmith (2002) menyatakan bahwa harga diri seseoarang dapat menentukan bagaimana cara seseorang berperilaku didalam lingkungannya. Peran 
harga diri dalam menentukkan perilaku ini dapat di lihat melalui proses berfikir, emosi, nilai, cita-cita dan tujuan yang hendak dicapai seseorang. Bila seseorang memiliki harga diri yang tinggi, maka perilakunya juga akan tinggi atau positf, sedangkan bila harga dirinya rendah maka akan tercermin pada perilakunya yang negatif. Individu yang merasa keberadaannya kurang berarti akan haus perhatian sehingga individu akan mencari dan mengadopsi perilaku yang menimbulkan perhatian bahkan menjadi sosok yang ditakuti untuk meningkatkan keberadaannya, salah satunya dengan mengadopsi perilaku bullying (Ghufron dan Risnawati, 2010).

\section{Hubungan Pengetahuan Tentang Bullying dengan Perilaku Bullying}

Berdasarkan analisis bivariat dapat diketahui bahwa ada hubungan yang bermakna antara pengetahuan tentang bullying dengan perilaku bullying dengan nilai p-value 0,002. Hal ini sejalan dengan hasil penelitian yang dilakukan oleh Fajrin pada tahun 2013 yang dilakukan di SMK PGRI Semarang menunjukkan bahwa ada hubungan tingkat pengetahuan dengan perilaku bullying di dapatkan nilai p-value sebesar 0.001. Semakin tinggi tingkat pengetahuan remaja tentang bullying, maka semakin rendah tingkat kejadian bullying, sebaliknya semakin rendah tingkat pengetahuan remaja tentang bullying maka semakin tinggi tingkat kejadian bullying.

Pada hasil penelitian ini juga dijelaskan bahwa remaja dengan pengetahuan kurang sebanyak 0,365 kali berpeluang lebih besar melakukan perilaku bullying di bandingkan remaja yang memiliki pengetahuan baik.

Pengetahuan adalah suatu pembentukan yang terus-menerus oleh seseorang yang setiap saat mengalami perkembangan dalam organisasi karena adanya pemahaman-pemahaman (Agus dan Budiman, 2014). Pengetahuan merupakan domain yang sangat penting dalam terbentuknya tindakan seseorang. Menurut teori Green (1980) menyatakan bahwa salah satu faktor yang menentukan perilaku seseorang yaitu pengetahuan. Tingkat pengetahuan yang baik diharapkan dapat membentuk perilaku positif seseorang untuk melakukan pencegahan dini terhadap perilaku bullying Notoatmodjo (2010).

Dari paparan diatas peneliti berpendapat bahwa pengetahuan berperan penting dalam menentukkan perilaku, apabila seseorang memliki pengetahuan baik maka akan memotivasi seseorang untuk memiliki perilaku yang positif. Sebagai contoh para siswa dilarang membully atau mencela satu sama lain, tanpa menjelaskan dampak apa yang akan terjadi, maka parasiswa akan mencoba untuk mencela karena tidak didasari 
dengan pengetahuan tentang bahaya membully atau dampak yang akan terjadi.

\section{Kesimpulan}

Mayoritas responden memiliki harga diri yang tinggi yaitu 97 (48,9\%). Sebagian besar responden memiliki pengetahuan yang baik sebanyak 104 (54,7\%). Sebagian besar responden melakukan perilaku bullying tinggi sebanyak 110 (57,9\%). Ada hubungan yang signifikan antara harga diri dengan perilaku bullying pada remaja dengan $p$-value $=0,000$. Ada hubungan antara pengetahuan tentang bullying pada remaja dengan p-value = 0,002 .

\section{Saran}

Bagi instansi pendidikan, dapat meningkatkan kegiatan program konseling yang terjadwal dan berkala disetiap kelas, serta melibatkan OSIS untuk mengadakan kegiatan terkait pencegahan bullying seperti adanya posterposter tentang bahaya bullyin untuk menambah wawasan atau kampanye anti bullying.

Bagi profesi keperawatan, dapat meningkatkan upaya promotif yaitu melakukan penyuluhan terhadap masyarakat khususnya remaja tentang pengetahuan bullying dan penyuluhan tentang konsep diri atau berkejasam dengan pihak UKS sekolah dalam menjalankan kegiatan ini. Bagi penelitain selanjutnya, dapat mengembangkan penelitian dengan menambah variabel lain yang akan diteliti sehingga dapat memperluas pengetahuan khsusnya terkait bullying pada remaja.

\section{Referensi}

Agus, dan Budiman. (2014). Kapita Selekta Kuesioner Pengetahuan dan Sikap Dalam Penelitian Kesehatan. Jakarta: Salemba Medika.

Astuti, P.R. (2008). Merendam Bullying: 3 cara efektif menanggunalangi kekerasan pada anak. Jakarta: PT Grasindo.

Capernito, L. (2009). Buku Saku Diagnosa Keperawatan Jiwa. Jakarta: EGC.

Ceilindri, R. dan Meita Santi Budiani. (2016). Harga Diri dan Konformitas dengan Perilaku Bullying Pada Siswa Sekolah Menengah Pertama. Jurnal Psikologi Teori dan Terapan. Vol. 6, No. 2, 64-70 2016.

Dharma, K.K. (2011). Metodologi Penelitian Keperawatan Panduan Melaksanakan dan Menetapkan Hasil Penelitian. Jakarta: CV. Trans Info Media.

Dermawan, D.\& Rusdi. (2013). Keperawatan Jiwa Konsep dan Kerangka Kerja Keperawatan Jiwa. Yogyakarta: Gosyen Publishing.

Fajrin, A.N. (2013). Hubungan Antara Tingkat Pengetahuan Dengan Perilaku Bullying Pada Remaja Di SMK PGRI Semarang. Semarang: Universitas Muhammadiyah Semarang.

Fithria \& Rahmi Auli. (2016). Faktor-Faktor yang Berhubungan Dengan Perilaku Bullying. Idea Nursing Journal. Vol.VII No.3 2016.

Ghufron, M. N \& Risnawita, R. (2010). TeoriTeori Psikologi. Yogyakarta: Ar-Ruzz Media Group. 
Hastono, S.P. (2011). Analisa Data Kesehatan.Depok: Fakultas Ilmu Kesehatan Masyarakat Universitas Indonesia

KPAI.(2017).Terima Aduan 26 ribu Kasus Bully Selama 2011-2017. www.kpai.go.id/berita/kpai-terima-aduan26-ribu-kasus-bullyi-selama-2011-2017. Diakses pada tanggal 15 Oktober 2018.

Notoatmodjo, S.(2010). Ilmu Perilaku Kesehatan. Jakarta: PT. Rineka Cipta.

Pemerintah Kota Bogor. (2016). JCI, RSMM, dan Pemkot sinergi hentikan perundungan (bullying) pada anak.www.kotabogor.go.id. Diakses pada tanggal 28 November 2018. Pukul 09.00 WIB.

Priyatna, A. (2010). Let's End Bullying: Memahami, Mencegah, dan Mengatasi Bullying. Jakarta: PT. Elex Media Komputindo.

Purnaningtyas, L.B, dan Achmad Mujab Masykur. (2015). Konsep Diri dan Kecenderungan Bullying Pada Siswa SMK Semarang. Jurnal Empati. Vol. 4 (4), 186190.

Stuart, G.W.(2016). Prinsip dan Praktik Keperawatan Kesehatan Jiwa Struat Edisi Indonesia. Singapura: Elsevier.

UNICEF. (2017). Laporan Tahunan Indonesia tahun 2015. Diakses pada tanggal 15 Oktober 2018.

Wawan, A., \& Dewi M. (2010). Teori dan Pengukuran Pengetahuan, Sikap, dan Perilaku Manusia. Yogyakarta: Nuha Medika.

Wiyani, N.A. (2012). Save Our Children From School Bullying. Yogyakarta: Ar-Ruzz Media. 